\title{
Publisher Correction: Structural insights into binding specificity, efficacy and bias of a $\boldsymbol{\beta}_{2}$ AR partial agonist
}

Matthieu Masureel, Yaozhong Zou, Louis-Philippe Picard, Emma van der Westhuizen (D), Jacob P. Mahoney, João P. G. L. M. Rodrigues, Thomas J. Mildorf, Ron O. Dror, David E. Shaw, Michel Bouvier (D), Els Pardon, Jan Steyaert, Roger K. Sunahara (D), William I. Weis, Cheng Zhang (D) and Brian K. Kobilka

Correction to: Nature Chemical Biology https://doi.org/10.1038/s41589-018-0145-x, published online 16 October 2018.

In the version of this paper originally published, the structure for epinephrine shown in Figure 1a was redrawn with an extra carbon. The structure has been replaced in the HTML and PDF versions of the article. The original and corrected versions of the structure are shown below.

Original

a

a<smiles>OCc1cc([C@@H](O)CNCCCCCCOCCCCc2ccccc2)ccc1O</smiles><smiles>CC(C)(C)NC[C@@H](O)c1ccc(O)c(CO)c1</smiles><smiles>CNC[C@H](O)c1ccc(O)c(CO)c1</smiles><smiles>Cc1ccccc1CC(C)(C)NC[C@H](O)C1=CC=C(O)C2NC(=O)COC12</smiles><smiles>OCc1cc([C@@H](O)CNCCCCCCOCCCCc2ccccc2)ccc1O</smiles><smiles>CC(C)(C)NC[C@@H](O)c1ccc(O)c(CO)c1</smiles><smiles>CNC[C@@H](O)c1ccc(O)c(O)c1</smiles><smiles>Cc1ccccc1CC(C)(C)NC[C@H](O)C1=CC=C(O)C2NC(=O)COC12</smiles>

Original and Corrected. 